\title{
ANALISIS KURVA PHILLIPS DAN HUKUM OKUN DI INDONESIA TAHUN 1986-2016
}

\author{
Oleh: \\ Prihartini Budi Astuti \\ e-mail : eti_toro@yahoo.com
}

\begin{abstract}
This study aims to determine the fit between Phillips Curve theory and Okun's law with the economic conditions that occurred in Indonesia in 1986-2016. This research is a descriptive quantitative research. Data used in the study is rate of economic growth, the unemployment rate and the inflation rate in Indonesia in 1986-2016. The data was taken from the website of Bank Indonesia and Badan Pusat Statistik. Quantitative analysis method used is correlation analysis. The analysis showed that there was no agreement between Phillips Curve theory and Okun's law with the economic conditions that occurred in Indonesia in 19862016. Phillip curves for compliance with the conditions of the Indonesian economy in 1986-2016, from data analysis obtained correlation coefficient of 0.16 with significance value of 0.931. From these figures, it can be concluded that there is a negative relationship but not significant between inflation and unemployment in Indonesia in 1986 - 2016. For Okun legal compliance with the conditions of the Indonesian economy in 1986 to 2016, from data analysis obtained correlation coefficient of - 0.110 with a significance value of 0,556. From these figures, it can be concluded that there is a negative relationship but not significant between economic growth and unemployment in Indonesia in 1986-2016
\end{abstract}

\section{PENDAHULUAN}

Tujuan negara membangun adalah untuk kesejahteraan rakyat, maka masalah pengangguran dan inflasi yang tinggi merupakan kondisi yang sangat tidak dikehendaki oleh suatu negara di manapun. Inflasi dan pengangguran adalah dua masalah ekonomi utama yang sering dihadapi oleh masyarakat suatu negara. Jika masalah inflasi dan pengangguran tidak terkendali, maka kedua masalah tersebut dapat mewujudkan efek buruk baik yang bersifat ekonomi, sosial, politik serta lingkungan dan budaya. Untuk menghindari berbagai efek buruk yang mungkin ditimbulkan oleh kedua masalah tersebut, secara sederhana yakni secara ekonomi makro diperlukan berbagai kebijakan ekonomi yang komprehensif. Dalam teori kurva Phillips, pengangguran yang tinggi memang akan cenderung mengurangi inflasi. Namun yang menarik di Indonesia, fenomena yang sering terjadi adalah ketika pengangguran tinggi tingkat inflasi juga masih tetap tinggi. Padahal, tujuan yang selalu dikehendaki untuk kedua masalah tersebut adalah rendah.

Pertumbuhan ekonomi, inflasi dan pengangguran adalah masalah jangka pendek dalam perekonomian. Inflasi sendiri diartikan sebagai meningkatnya harga-harga secara 
umum dan terus menerus. Kenaikan dari satu atau dua barang saja tidak dapat dikatakan sebagai inflasi kecuali bila kenaikan itu meluas (atau mengakibatkan kenaikan harga) pada barang lainnya. Semua negara di dunia selalu menghadapi permasalahan inflasi, sehingga dapat dikatakan bahwa inflasi yang terjadi pada suatu negara dapat digunakan sebagai indikator baik buruknya perekonomian suatu negara. Bagi negara yang perekonomiannya baik, tingkat inflasi yang terjadi berkisar antara 2 sampai 4 persen per tahun. Tingkat inflasi yang berkisar antara 2 sampai 4 persen dikatakan tingkat inflasi yang rendah.

Indikator prestasi perekonomian yang lainnya adalah tingkat pengangguran. Berdasarkan tingkat pengangguran, dapat dilihat kondisi suatu negara, apakah perekonomiannya berkembang atau lambat dan atau bahkan mengalami kemunduran. Selain itu dengan tingkat pengangguran, dapat dilihat pula ketimpangan atau kesenjangan distribusi pendapatan yang diterima suatu masyarakat negara tersebut. Pengangguran dapat terjadi sebagai akibat dari tingginya tingkat perubahan angkatan kerja yang tidak diimbangi dengan adanya lapangan pekerjaan yang cukup luas serta penyerapan tenaga kerja yang cenderung kecil persentasenya, Hal ini disebabkan rendahnya tingkat pertumbuhan penciptaan lapangan kerja untuk menampung tenaga kerja yang siap bekerja. Kondisi pengangguran yang tinggi merupakan pemborosan sumber daya dan potensi yang ada, menjadi beban keluarga dan masyarakat, sumber utama kemiskinan, dapat mendorong peningkatan keresahan sosial dan kriminal yang dapat menghambat pembangunan dalam jangka panjang.

Pertumbuhan ekonomi juga merupakan salah satu indikator yang amat penting dalam menilai kinerja suatu perekonomian, terutama untuk melakukan analisis tentang hasil pembangunan ekonomi yang telah dilaksanakan suatu negara atau suatu daerah. Ekonomi dikatakan mengalami pertumbuhan apabila produksi barang dan jasa meningkat dari tahun sebelumnya. Pertumbuhan ekonomi menunjukkan sejauh mana aktivitas perekonomian dapat menghasilkan tambahan pendapatan atau kesejahteraan masyarakat pada periode tertentu. Pertumbuhan ekonomi suatu negara atau suatu wilayah yang terus menunjukkan peningkatan menggambarkan bahwa perekonomian negara atau wilayah tersebut berkembang dengan baik.

Keberhasilan kinerja perekonomian suatu negara dapat dilihat dari tingkat pertumbuhan ekonomi, tingkat pengangguran, dan inflasi. Tiga variabel makro tersebut saling berkaitan. Dalam teori ekonomi makro, hubungan antara tingkat pertumbuhan ekonomi dengan tingkat pengangguran terdapat dalam hukum Okun (Okun's Law). Hukum Okun menyatakan bahwa untuk setiap 2 (dua) persen kemerosotan GNP dari GNP potensialnya, tingkat pengangguran akan melonjak 1 (satu) persen. Sedangkan hubungan antara inflasi dan pengangguran dinyatakan dalam Kurva Phillip. Kurva Phillips pertama kali dikemukakan oleh A.W. Phillips, pada tahun 1958. Phillips menyimpulkan bahwa terdapat hubungan negatif antara pengangguran dan perubahan tingkat upah. Phillips menggunakan perubahan tingkat upah karena upah 
akan mempengaruhi harga barang dan jasa dan pada akhirnya juga mempengaruhi inflasi.

Pengangguran merupakan masalah bagi semua negara di dunia. Tingkat pengangguran yang terlalu tinggi akan mengganggu stabilitas nasional setiap negara, sehingga setiap negara akan berusaha untuk mempertahankan tingkat pengangguran pada tingkat yang rendah. Selama kurun waktu 4-5 tahun terakhir perekonomian Indonesia bukan merupakan yang tertinggi, namun dinilai paling stabil dibandingkan negara lainnya. Pertumbuhan ekonomi Indonesia berada di kisaran 6,1 - 6,3 persen pada tahun 2012 dengan ditopang oleh sektor konsumsi yang tinggi yang dikombinasikan dengan ekspor dan investasi. Pertumbuhan ekonomi Indonesia menunjukkan tren positif sejak tahun 2000 hingga tahun 2012. GDP tahun 2000 berada pada angka Rp1.389.769,9 milliar dan pada tahun 2012 Rp2.618.139,2 milliar (GDP Harga Konstan tahun 2000).

Selain dipengaruhi oleh tingkat pertumbuhan ekonomi, tingkat pengangguran juga dipengaruhi oleh tingkat inflasi, sebagaimana tercermin melalui kurva Phillips. Tujuan penyusunan tingkat inflasi adalah untuk memperoleh indikator yang menggambarkan kecenderungan umum tentang perkembangan harga. Tujuan tersebut penting dicapai karena indikator tersebut dapat dipakai sebagai salah satu informasi dasar untuk pengambilan keputusan baik tingkat ekonomi mikro atau makro, baik fiskal maupun moneter. Pada tingkat mikro, rumah tangga/masyarakat misalnya, dapat memanfaatkan angka inflasi untuk dasar penyesuaian nilai pengeluaran kebutuhan sehari-hari dengan pendapatan mereka yang relatif tetap. Pada tingkat korporasi, angka inflasi dapat dipakai untuk perencanaan pembelanjaan dan kontrak bisnis. Dalam lingkup yang lebih luas (makro), angka inflasi menggambarkan kondisi/stabilitas moneter dan perekonomian.

\begin{tabular}{lrr}
\multicolumn{1}{c}{ Tingkat inflasi yang tinggi } \\
merupakan indikasi & awal \\
memburuknya perekonomian & suatu \\
negara. Tingkat inflasi yang tinggi & tapat mendorong bank & sentral \\
dapat & bunga
\end{tabular} sehingga menyebabkan kontraksi atau pertumbuhan negatif di sektor riil. Lebih jauh lagi akan menyebabkan pengangguran yang makin meningkat. Dalam jangka pendek kenaikan inflasi menunjukkan pertumbuhan perekonomian namun dalam jangka panjang kenaikan inflasi yang tinggi dapat memberikan dampak buruk. Tingginya tingkat inflasi menyebabkan harga barang domestik relatif lebih mahal dibandingkan dengan harga barang impor. Masyarakat terdorong untuk membeli barang impor dibandingkan barang domestik. Hal ini berakibat nilai ekspor cenderung turun dan nilai impor naik. Kurang bersaingnya harga produk domestik menyebabkan rendahnya permintaan produk dalam negeri. Produksi menjadi berkurang karena sejumlah pengusaha akan mengurangi produksi. Produksi berkurang menyebabkan sejumlah pekerja kehilagan pekerjaannya sehingga pengangguran meningkat.

\section{IDENTIFIKASI MASALAH}

Keberhasilan kinerja perekonomian suatu negara dapat dilihat dari tingkat pertumbuhan ekonomi, tingkat pengangguran, dan 
inflasi. Dalam teori ekonomi makro, hubungan antara tingkat pertumbuhan ekonomi dengan tingkat pengangguran terdapat dalam hukum Okun (Okun's Law). Hukum Okun menyatakan bahwa untuk setiap 2 (dua) persen kemerosotan GNP dari GNP potensialnya, tingkat pengangguran akan melonjak 1 (satu) persen, demikian sebaliknya. Sedangkan hubungan antara inflasi dan pengangguran dinyatakan dalam Kurva Philllip. Phillips menyimpulkan bahwa terdapat hubungan negatif antara pengangguran dan perubahan tingkat upah. Penelitian ini bermaksud untuk melihat kesesuaian antara Hukum Okun dan Kurva Phillips dengan kondisi perekonomian yang terjadi di Indonesia pada tahun 1986-2016, dengan pertanyaan penelitian sebagai berikut:

a. Bagaimana kesesuaian antara teori Kurva Phillips dengan kondisi perekonomian Indonesia pada tahun 1986 - 2016?

b. Bagaimana kesesuaian antara teori Hukum Okun dengan kondisi perekonomian Indonesia pada tahun 1986 - 2016?

\section{KAJIAN PUSTAKA}

\section{Kurva Phillips}

"Hubungan paling penting dalam ekonomi makro mungkin adalah kurva Phillips". Pernyataan ini dingkapkan oleh ekonom Gregory Akerlof pada kuliah yang diberikannya pada saat ia menerima Nobel Prize pada tahun
2001. Kurva Phillips adalah hubungan jangka pendek antara inflasi dan penganggran.

Pada tahun 1958, ekonom yang bernama A.W. Phillips menerbitkan sebuah artikel pada jurnal Inggris "Economica". Artikel tersebut berjudul "The Relationship between Unemployment and the Rate of Change of Money Wages in the United Kingdom 1861-1957". Dalam artikel tersebut, Phillips menunjukkan korelasi negatif antara tingkat pengangguran dan tingkat inflasi. Dengan kata lain, Phillips menunjukkan bahwa tahuntahun dengan tingkat pengangguran yang rendah cenderung memiliki tingkat inflasi yang tinggi, sedangkan tahun-tahun dengan pengangguran yang tinggi cenderung memiliki inflasi rendah (Mankiw, 2014:272)

A.W. Phillips menggambarkan bagaimana sebaran hubungan antara inflasi dengan tingkat pengangguran didasarkan pada asumsi bahwa inflasi merupakan cerminan dari adanya kenaikan permintaan agregat. Dengan naiknya permintaan agregat, maka sesuai dengan teori permintaan, jika permintaan naik maka harga akan naik. Dengan tingginya harga (inflasi) maka untuk memenuhi permintaan tersebut produsen meningkatkan kapasitas produksinya dengan menambah tenaga kerja (asumsinya tenaga kerja merupakan satu-satunya input yang dapat meningkatkan output). Akibat dari peningkatan permintaan tenaga kerja maka dengan naiknya hargaharga (inflasi), pengangguran berkurang. 


\section{Gambar II-1. Kurva Phillips}

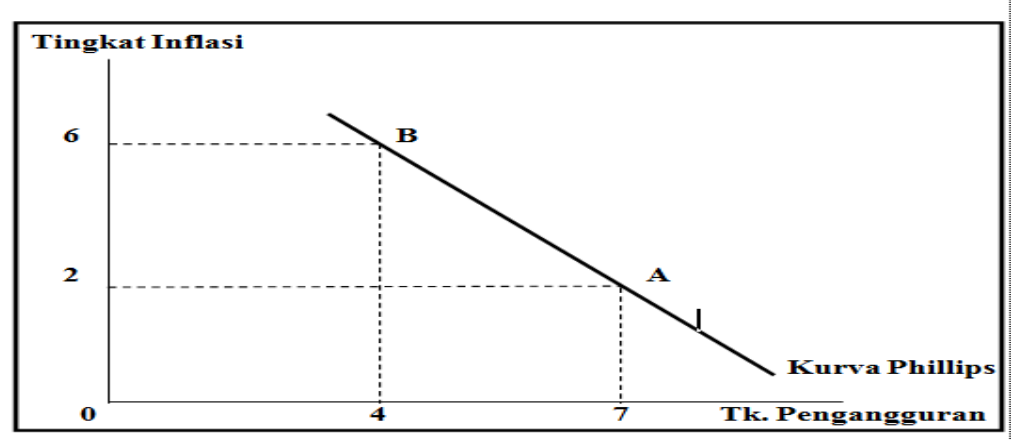

\section{Hukum Okun}

Arthur Okun (1929 - 1979) adalah salah seorang pembuat kebijakan paling kreatif pada era sehabis perang. Dia memperhatikan faktor-faktor pembangunan yang membantu Amerika Serikat menelusuri dan mengatur usahanya. Ia membuat konsep output potensial dan menunjukkan hubungan antara output dan penganggur. Penganggur biasanya bergerak bersamaan dengan output pada siklus bisnis. Pergerakan bersama dari output dan pengangguran yang luar biasa ini berbarengan dengan hubungan numerikal yang sekarang dikenal dengan nama Hukum Okun.

Hukum Okun menyatakan bahwa untuk setiap penurunan 2 persen GDP yang berhubungan dengan GDP potensial, angka pengangguran meningkat sekitar 1 persen. Hukum Okun menyediakan hubungan yang sangat penting antara pasar output dan pasar tenaga kerja, yang menggambarkan asosiasi antara pergerakan jangka pendek pada GDP riil dan perubahan angka pengangguran (Samuelson and Nordhaus, 2004: 365 366).

\section{Pengangguran}

Definisi pengangguran dalam arti luas adalah penduduk yang tidak bekerja tetapi sedang mencari pekerjaan atau sedang mempersiapkan suatu usaha baru atau penduduk yang tidak mencari pekerjaan karena sudah diterima bekerja tetapi mulai bekerja.

Pengangguran (unemployment) merupakan kenyataan yang dihadapi tidak saja oleh negara-negara sedang berkembang (developing countries), akan tetapi juga negara-negara yang sudah maju (developed countries). Secara umum, pengangguran didefinisikan sebagai suatu keadaan dimana seseorang yang tergolong dalam kategori angkatan kerja (labor force) tidak memiliki pekerjaan dan secara aktif sedang mencari pekerjaan (Nanga, 2001). Seseorang yang tidak bekerja tetapi secara aktif mencari pekerjaan tidak dapat digolongkan sebagai penganggur. Selain itu pengangguran diartikan sebagai suatu keadaan dimana seseorang yang tergolong dalam angkatan kerja ingin mendapatkan pekerjaan belum dapat memperolehnya (Sukirno, 2000). 


\section{Inflasi}

Inflasi adalah suatu keadaan yang ditimbulkan oleh tidak adanya keseimbangan antara permintaan akan barang-barang dan persediaannya, yaitu permintaan melebihi persediaan dan semakin besar perbedaan itu semakin besar bahaya yang ditimbulkan oleh inflasi bagi kesehatan ekonomi (Soesastro,2005).

Inflasi terjadi jika proses kenaikan harga berlangsung secara terus menerus dan saling mempengaruhi. Inflasi juga dikatakan sebagai ukuran terbaik bagi perekonomian dalam suatu negara, tetapi bukan berarti jika suatu Negara berada dalam kondisi inflasi yang tinggi maka negara tersebut sangat baik perekonomiannya dan masyarakatnya sejahtera secara keseluruhan.

Dari definisi tersebut, ada tiga komponen yang harus dipenuhi agar dapat dikatakan telah terjadi inflasi (Pratama,2008), yaitu sebagai berikut:

1. Kenaikan harga. Harga suatu komoditas dikatakan naik jika menjadi lebih tinggi daripada harga periode sebelumnya.

2. Bersifat umum. Kenaikan harga suatu komoditas belum dapat dikatakan inflasi jika kenaikan tersebut tidak menyebabkan hargaharga secara umum naik.

3. Berlangsung terus-menerus. Kenaikan harga yang bersifat umum juga belum akan memunculkan inflasi, jika terjadinya hanya sesaat. Karena itu perhitungan inflasi dilakukan dalam rentang waktu minimal bulanan.

Jika dilihat dari faktor penyebab timbulnya, inflasi dapat dibedakan ke dalam tiga macam (Pratama, 2008) yaitu:

1. Inflasi tarikan permintaan (demand pull inflation)

Inflasi tarikan permintaan atau disebut juga inflasi sisi permintaan (demand side inflation) atau inflasi karena guncangan permintaan (demand shock inflation) adalah inflasi yang terjadi sebagai akibat dari adanya kenaikan permintaan agregat (AD) yang terlalu besar atau pesat dibandingkan dengan penawaran atau produksi agregat. Secara grafik, demand pull inflation dapat dijelaskan dengan menggunakan gambar sebagai berikut:

\section{Gambar II-2}

\section{Demand-Pull Inflation}

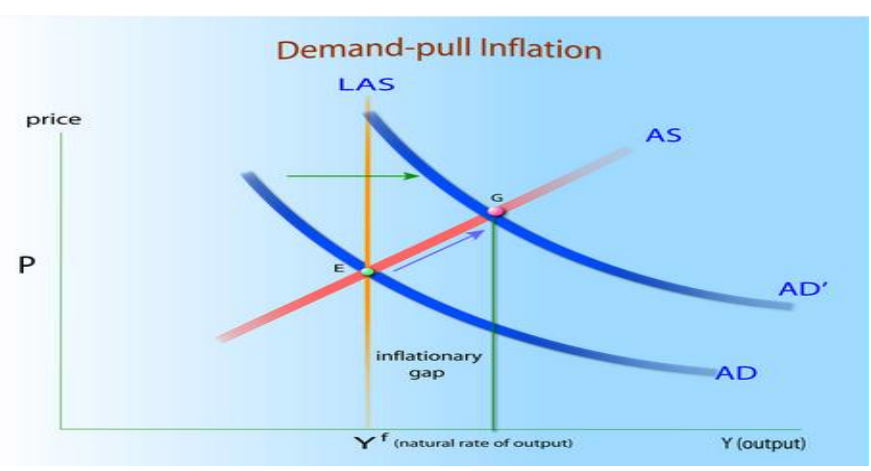


2. Inflasi dorongan biaya (cost-pust inflation)

Inflasi dorongan biaya atau juga sering disebut inflasi sisi penawaran (supply-side inflation) atau inflasi karena guncangan penawaran (supply shock inflation) adalah inflasi yang terjadi sebagai akibat dari adanya kenaikan biaya produksi yang pesat dibandingkan dengan produktivitas dan efisiensi, yang menyebabkan perusahaan mengurangi supply barang dan jasa mereka ke pasar. Secara grafik, supply-side inflation dapat dijelaskan dengan menggunakan kurva sebagai berikut:

\section{Gambar II-3. Cost-Push Inflation}

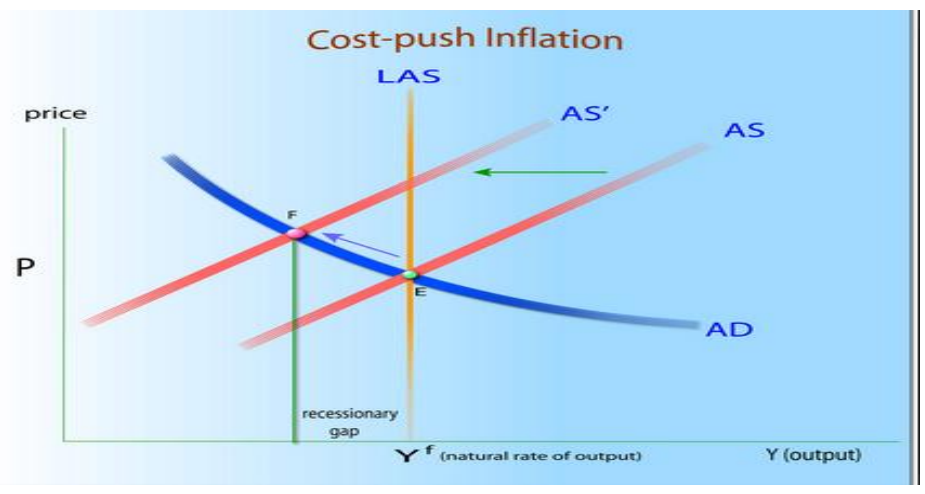

\section{Pertumbuhan Ekonomi}

Simon Kuznets mendefinisikan pertumbuhan ekonomi sebagai kenaikan jangka panjang dalam kemampuan suatu negara untuk menyediakan semakin banyak jenis barang-barang ekonomi kepada penduduknya, kemampuan ini tumbuh sesuai dengan kemajuan teknologi, dan penyesuaian kelembagaan dan ideologis yang diperlukannya.

Pertumbuhan ekonomi adalah sebagian dari perkembangan kesejahteraan masyarakat yang diukur dengan besarnya pertumbuhan domestik regional bruto per kapita (PDRB per kapita). Pertumbuhan ekonomi berarti perkembangan kegiatan dalam perekonomian yang menyebabkan barang dan jasa yang diproduksikan dalam masyarakat bertambah dan kemakmuran masyarakat meningkat (Sukirno, 1994). Menurut Suryana (2000), pertumbuhan ekonomi diartikan sebagai kenaikan GDP (Gross Domestic Product) tanpa memandang bahwa kenaikan itu lebih besar atau lebih kecil dari pertumbuhan penduduk dan tanpa memandang apakah ada perubahan dalam struktur ekonominya. Menurut Boediono (1992) pertumbuhan ekonomi adalah suatu proses dari kenaikan output perkapita dalam jangka waktu yang panjang. Pertumbuhan ekonomi disini meliputi 3 aspek yaitu :

1. Pertumbuhan ekonomi merupakan suatu proses (aspek ekonomis) suatu perekonomian berkembang, berubah dari waktu ke waktu.

2. Pertumbuhan ekonomi berkaitan dengan adanya kenaikan output 
perkapita, dalam hal ini ada 2 aspek penting yaitu output total dan jumlah penduduk. Output perkapita adalah output total dibagi jumlah penduduk.

3. Pertumbuhan ekonomi dikaitkan dengan perspektif waktu jangka panjang. Dikatakan tumbuh bila dalam jangka panjang waktu yang cukup lama (5 tahun) mengalami kenaikan output.

\section{Kerangka Pikir Penelitian \\ Gambar II-4 \\ Kerangka Pikir Penelitian}

\section{Tingkat Inflasi}

\section{Tingkat Pertumbuhan Ekonomi}

\section{METODE PENELITIAN}

Penelitian ini merupakan penelitian kuantitatif deskriptif. Subyek dalam penelitian ini adalah kondisi perekonomian Indonesia, sedangkan obyek dalam penelitian ini adalah analisis kurva Phillips dan hukum Okun di Indonesia tahun 1988 - 2015.

\section{Jenis dan Sumber Data}

Jenis data yang dipakai dalam penelitian ini adalah data sekunder, yaitu data yang diperoleh dari instansi terkait yang menerbitkan data tingkat pertumbuhan ekonomi, tingkat inflasi dan tingkat pengangguran di Indonesia, serta data-data dari literatur lain yang ada kaitannya dengan penelitian ini. Data sekunder yang diperlukan dalam penelitian ini yaitu data tingkat pertumbuhan ekonomi, tingkat inflasi dan tingkat pengangguran tahun 19882015 di Indonesia serta data penunjang lain yang mendukung penelitian ini.

\section{Definisi Operasional Variabel}

Variabel yang akan diteliti dalam penelitian ini adalah tingkat pertumbuhan ekonomi, tingkat inflasi dan tingkat pengangguran. Sedangkan definisi operasionalnya adalah sebagai berikut:

1. Tingkat pertumbuhan ekonomi Pertumbuhan ekonomi diartikan sebagai proses kenaikan kapasitas 
produksi suatu perekonomian yang diwujudkan dalam bentuk kenaikan pendapatan nasional.

2. Tingkat inflasi

Inflasi diartikan sebagai suatu keadaan dimana terjadi kenaikan tingkat harga secara umum, baik barang-barang, jasa-jasa maupun faktor-faktor produksi

3. Tingkat pengangguran

Pengangguran adalah penduduk yang tidak bekerja dan sedang mencari pekerjaan atau sedang mempersiapkan suatu usaha baru atau penduduk yang tidak mencari pekerjaan karena sudah diterima bekerja tetapi belum mulai bekerja

\section{Metode Penelitian}

Berpijak pada masalah dan tujuan yang telah dirumuskan sebelumnya, maka penelitian ini menggunakan metode Analisis Korelasi. Analisis korelasi adalah metode yang digunakan untuk menganalisis tentang derajat hubungan antara variabel-variabel. Metode analisis korelasi dipilih karena penelitian ini akan menganalisis hubungan dua variabel atau lebih, yakni hubungan variasi dalam satu variabel dengan variasi dalam variabel lain (Arifin, 2011:48).
Dalam penelitian ini, hubungan yang akan diteliti adalah hubungan antara tingkat pertumbuhan ekonomi dengan tingkat pengangguran (Hukum Okun) serta hubungan antara tingkat inflasi dengan tingkat pengangguran (Kurva Phillips) di Indonesia tahun 1986-2016. Analisis data akan dilakukan dengan menggunakan analisis korelasi. Analisis ini digunakan untuk mengetahui bagaimana hubungan antara tingkat pertumbuhan ekonomi dengan tingkat pengangguran (Hukum Okun) serta hubungan antara tingkat inflasi dengan tingkat pengangguran (Kurva Phillips) di Indonesia tahun 1986-2016.

\section{Teknik Analisis Data}

\section{a. Analisis Korelasi}

Analisis korelasi dengan menggunakan uji koefisien korelasi dimaksud untuk mengetahui derajat hubungan antara variabel $\mathrm{X}$ (tingkat pengangguran) dengan variabel $\mathrm{Y}$ (tingkat inflasi ; tingkat pertumbuhan ekonomi). Mencari koefisien korelasi antara variabel $\mathrm{X}$ dengan variabel $\mathrm{Y}$ dengan menggunakan rumus korelasi Product Moment sebagai berikut (Sugiyono, 2012 : 228)

$$
r_{x y}=\frac{n \sum X_{i} Y_{i}-\left(\sum X_{i}\right)\left(\sum Y_{i}\right)}{\sqrt{\left\{n \sum X_{i}^{2}-\left(\sum X_{i}\right)^{2}\right\}\left\{n \sum Y_{i}^{2}-\left(\sum Y_{i}\right)^{2}\right\}}}
$$

Keterangan :

Rxy $\quad=$ koefisien korelasi

$\Sigma \mathrm{X}$ : variabel $\mathrm{X}$ (tingkat pengangguran)

$\Sigma Y \quad$ : variabel Y (tingkat pertumbuhan ekonomi;tingkat inflasi)

$\mathrm{N}$ : banyaknya data

Untuk mengidentifikasi tinggi rendahnya korelasi, digunakan kriteria penafsiran seperti pada tabel dibawah ini : 
Tabel III-1

Interval Koefisien Korelasi

\begin{tabular}{|c|c|}
\hline Interval Koefisien & Tingkat Hubungan \\
\hline $0,000-0,199$ & Sangat Rendah \\
\hline $0,200-0,399$ & Rendah \\
\hline $0,400-0,599$ & Sedang \\
\hline $0,600-0,799$ & Kuat \\
\hline $0,800-1,000$ & Sangat Kuat \\
\hline
\end{tabular}

b. Uji Signifikansi

Menguji tingkat signifikansi korelasi antara variabel $\mathrm{X}$ dengan variabel $\mathrm{Y}$ setelah nilai $\mathrm{r}$ diperoleh, kemudian disubstitusikan ke dalam rumus sebagai berikut (Nana Sudjana, 2001 : 377):

$$
\begin{aligned}
& (5,81 \text { persen }) \text {. Ditinjau berdasarkan }
\end{aligned}
$$

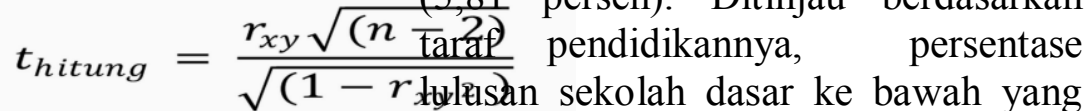

Keterangan :

$$
\begin{array}{ll}
\mathrm{t} \text { hitung } & =\text { nilai } \mathrm{t} \text { hitung } \\
\mathrm{R} & =\text { koefisien korelasi }
\end{array}
$$$$
\text { hasil } r \text { hitung }
$$$$
\mathrm{N} \quad=\text { jumlah data }
$$

Kriteria pengujian terhadap uji dua pihak dengan $\mathrm{dk}=(\mathrm{n}-3)$ pada tingkat signifikansi 95\% diperoleh kriteria sebagai berikut:

Jika $t_{\text {hitung }}>\mathrm{t}_{\text {tabel }}$ maka Ho ditolak dan $\mathrm{H}_{1}$ diterima

Jika $t_{\text {hitung }}<t_{\text {tabel }}$ maka Ho diterima dan $\mathrm{H}_{1}$ ditolak

\section{HASIL PENELITIAN DAN PEMBAHASAN}

\section{Analisis Deskriptif}

Badan Pusat Statistik (BPS) melansir pertumbuhan ekonomi RI selama tahun 2015 mencapai 4,79 persen. Adapun untuk kuartal IV-2015, ekonomi tumbuh 5,04 persen lebih tinggi dari kuartal sebelumnya yang hanya 4,73 persen.
Untuk data tingkat pengangguran di Indonesia, tingkat pengangguran terbuka pada Februari 2016 mencapai 7,02 juta orang atau 5,5 persen. Namun bila dibandingkan dengan Februari 2015, yang mencapai 7,45 juta orang menganggur menurun, yakni dari 3,61 persen menjadi 3,44 persen. Tingkat pengangguran tertinggi adalah lulusan sekolah menengah kejuruan dengan persentase 9,84 persen, meningkat dibandingkan kondisi pada bulan Februari 2015 sebesar 9,05 persen. Persentase penduduk berpendidikan sekolah menengah pertama yang menganggur juga menurun, yakni dari 7,14 persen menjadi 5,76 persen. Begitu juga dengan persentase penduduk berpendidikan sekolah menengah atas menurun dari 8,17 persen menjadi 6,95 persen. Adapun persentase penduduk berpendidikan diploma I, II, dan III yang menganggur juga menurun. Sedangkan berdasarkan wilayah, kata dia, tingkat pengangguran tertinggi terjadi di Kepulauan Riau dengan 9,03 persen dan terendah terjadi di Bali dengan 2,12 persen.

Dari sisi perkembangan tingkat inflasi, Badan Pusat Satistik mencatat inflasi sepanjang 2015 sebesar 3,35 jumlah pengangguran tersebut menurun 
persen (year on year), merupakan inflasi tahunan terendah sejak 2010, dan mengindikasikan perbaikan stabilitas harga barang dan jasa, meskipun turut dipengaruhi dari perlambatan ekonomi. Laju inflasi tahunan sejak 2010 hingga 2014, masing-masing adalah 6,96 persen, 3,69 persen, 4,3 persen, 8,38 persen dan 8,36 persen.

\section{Tingkat Pertumbuhan Ekonomi}

Seperti sudah dijelaskan secara singkat diatas, tingkat pertumbuhan ekonomi RI selama tahun 2015 mencapai 4,79 persen. Mengawali tahun 2016, Indonesia harus mampu membangun optimisme untuk menghadapi setiap situasi ekonomi, baik global maupun domestik. Namun, kondisi ini harus tetap diwaspadai karena mengingat kondisi ekonomi global yang lebih rentan dengan krisis karena mudah berubah-ubah.

Berkaca dari tahun lalu, pengaruh terbesar bagi ekonomi Indonesia di 2016 antara lain, yaitu: pertama, perlambatan ekonomi Tiongkok. Sebagai mitra dagang terbesar Indonesia, perlambatan ekonomi di Tiongkok berarti memberi pengaruh pada kegiatan ekspor. Perlu dicatat, ekonomi dunia juga mendapat pengaruh yang sama atas perlambatan ini. Melihat hal ini, tentunya pola ekspor Indonesia pun harus mulai diubah, dari barang mentah menjadi barang jadi/ barang konsumsi. Kedua, masih rendahnya harga minyak. Secara otomatis, minyak menjadi referensi harga bagi komoditas lain, dimana nilai minyak yang rendah berimbas pada harga komoditas yang rendah. Indonesia sendiri mulai berusaha untuk mengurangi ketergantungan kepada komoditas pada 2015 lalu. Di dalam negeri, penurunan harga minyak ini mengganggu ide pengembangan energi terbarukan karena harganya menjadi lebih murah untuk dikonsumsi.

Ketiga, kebijakan suku bunga Bank Sentral Amerika Serikat, yang juga pasti berpengaruh pada kondisi ekonomi dalam negeri, khususnya sektor keuangan. Hal ini tentunya harus kita antisipasi sehingga sektor keuangan Indonesia tetap dalam kondisi stabil. Pemerintah berkomitmen untuk melakukan koordinasi agar dapat menjaga fundamental ekonomi baik makro, moneter, maupun fiskal. Salah satu hal yang penting adalah bagaimana mengoptimalkan belanja dalam Anggaran Pendapatan dan Belanja (APBN) karena ini menjadi salah satu faktor penyokong pertumbuhan tahun 2016.

Antara tahun 1965 sampai 1997 perekonomian Indonesia tumbuh dengan persentase ratarata per tahunnya hampir tujuh persen. Akan tetapi, krisis finansial Asia yang meletus pada akhir tahun 1990-an mengakibatkan dampak sangat negatif untuk perekonomian Indonesia, menyebabkan penurunan Produk Domestik Bruto (PDB) sebesar $13,6 \%$ pada tahun 1998 dan pertumbuhan yang terbatas pada $0,3 \%$ di 1999. Antara periode 2000-2004, pemulihan ekonomi terjadi dengan rata-rata pertumbuhan PDB pada 4,6\% setiap tahunnya. Setelah itu, pertumbuhan PDB berakselerasi 
(dengan pengecualian pada tahun 2009, akibat guncangan dan ketidakjelasan finansial global, pertumbuhan PDB Indonesia jatuh menjadi 4,6\%, sebuah angka yang masih mengagumkan) dan memuncak pada 6,5\% di 2011. Kendati begitu, setelah 2011 ekspansi perekonomian Indonesia mulai sangat melambat.

Tabel IV-1. Tingkat Pertumbuhan Ekonomi Indonesia Tahun 1969 - 2016

\begin{tabular}{|c|c|c|c|l|c|c|c|c|c|}
\hline Tahun & P.E & Tahun & P.E & Tahun & P.E & Tahun & P.E & Tahun & P.E \\
\hline 1969 & 6,82 & 1979 & 7,32 & 1989 & 7,46 & 1999 & 0,79 & 2009 & 4,10 \\
\hline 1970 & 7,55 & 1980 & 9,88 & 1990 & 7,24 & 2000 & 4,92 & 2010 & 6,22 \\
\hline 1971 & 7,02 & 1981 & 7,93 & 1991 & 6,95 & 2001 & 3,64 & 2011 & 6,49 \\
\hline 1972 & 7,04 & 1982 & 2,25 & 1992 & 6,46 & 2002 & 4,50 & 2012 & 6,26 \\
\hline 1973 & 8,10 & 1983 & 4,19 & 1993 & 6,50 & 2003 & 4,78 & 2013 & 5,78 \\
\hline 1974 & 7,63 & 1984 & 6,98 & 1994 & 7,54 & 2004 & 5,03 & 2014 & 5,02 \\
\hline 1975 & 4,98 & 1985 & 2,46 & 1995 & 8,22 & 2005 & 5,69 & 2015 & 4,79 \\
\hline 1976 & 6,89 & 1986 & 5,87 & 1996 & 7,82 & 2006 & 5,50 & 2016 & 5.02 \\
\hline 1977 & 8,76 & 1987 & 4,93 & 1997 & 4,70 & 2007 & 6,28 & - & \\
\hline 1978 & 6,77 & 1988 & 5,78 & 1998 & $-13,13$ & 2008 & 6,06 & - & \\
\hline
\end{tabular}

\section{Sumber : BPS dan BI, diolah}

Ada beberapa faktor yang menjelaskan perlambatan ekonomi ini:

a. Perlambatan pertumbuhan ekonomi global.

Setelah mengalami rebound dari resesi global yang besar (20072009), laju pertumbuhan ekonomi di seluruh dunia menurun pada periode 2010-2014. Yang paling menyebabkan kekuatiran adalah semakin menurunnya laju pertumbuhan perekonomian RRT. Negara dengan perekonomian terbesar kedua di dunia ini bertumbuh 7,3\% pada basis year-onyear pada tahun 2014, level terendah dalam 24 tahun terakhir. Menurunnya ekspansi perekonomian di RRT segera memberikan dampak pada Indonesia karena kedua negara adalah mitra dagang yang penting (RRT berkontribusi untuk hampir sepersepuluh dari total ekspor Indonesia). Diperkirakan bahwa untuk setiap penurunan $1 \%$ dari pertumbuhan PDB RRT, ekspansi

perekonomian Indonesia akan berkurang $0,5 \%$.

b. Menurunnya harga-harga komoditi Perlambatan ekonomi global barubaru ini (dan terutama perlambatan ekonomi RRT) menyebabkan penurunan harga-harga komoditi ke level yang rendah selama bertahuntahun. Sebagai negara eksportir komoditi yang besar (dan kekurangan industri hilir yang berkembang baik), performa ekspor Indonesia sangat terpengaruh saat harga komoditi (seperti batubara dan minyak kelapa sawit) rendah. Rendahnya harga komoditikomoditi tidak hanya disebabkan oleh permintaan global yang lebih lemah namun juga karena kelebihan suplai. Pada masa boom komoditi di tahun 2000-an dan setelah resesi besar yang terjadi di akhir tahun 2000-an (ketika institusi-institusi seperti Bank Dunia dan International Monetary Fund menerbitkan proyeksi pertumbuhan global yang terlalu optimis) banyak 
perusahaan memasuki sektor komoditi -atau perusahaanperusahaan komoditi yang telah ada berinvestasi untuk meningkatkan kapasitas produksi- dan menyebabkan timbunan suplai sehingga menekan turun harga komoditi.

c. Tingginya tingkat suku bunga Bank Indonesia

Tingkat suku bunga yang tinggi membatasi pertumbuhan kredit dan karenanya mengurangi pertumbuhan ekonomi. Sejak pertengahan tahun 2013, Bank Indonesia meningkatkan suku bunga acuannya (BI-Rate) dari level terendah dalam sejarah pada $5,75 \%$ kemudian secara bertahap, namun agresif, naik menjadi $7,75 \%$ di akhir 2014. Bank Indonesia mengetatkan kebijakan moneternya dalam rangka melawan inflasi yang tinggi (yang meningkat tajam setelah beberapa reformasi subsidi bahan bakar), mengurangi defisit transaksi berjalan yang lebar, dan mendukung rupiah yang telah dibebani oleh tekanan-tekanan berat karena pengetatan moneter di Amerika Serikat (karena itu, Bank Indonesia lebih memilih stabilitas finansial dibandingkan pertumbuhan ekonomi yang lebih tinggi). Capital outflows besar-besaran dari negaranegara berkembang, termasuk Indonesia, terjadi di sebagian besar waktu di tahun 2013 karena ancaman penurunan program pembelian obligasi senilai 85 miliar dollar Amerika Serikat (AS) setiap bulannya (quantitative easing AS). Pada tahun 2015, capital outflows dari negara-negara berkembang muncul kembali karena dunia sedang bersiap-siap untuk suku bunga AS yang lebih tinggi.

\section{Tingkat Pengangguran}

Dengan jumlah total penduduk sekitar 255 juta orang, Indonesia adalah negara dengan penduduk terpadat keempat dunia setelah China, India dan Amerika Serikat. Negara Indonesia juga juga memiliki populasi penduduk yang muda karena lebih dari setengah dari total penduduk Indonesia berusia dibawah 30 tahun. Jika kedua hal tersebut digabungkan, Indonesia adalah negara yang memiliki kekuatan tenaga kerja yang besar.

Salah satu karakteristik Indonesia adalah bahwa pengangguran yang cukup tinggi yang dihadapi oleh tenaga kerja muda yang berusia 15-29 tahun, jauh lebih tinggi dari angka ratarata pengangguran secara nasional. Dilihat dari sisi sektoral, sektor yang paling banyak menyerap tenaga kerja adalah sektor pertanian, disusul oleh sektor perdagangan dan sektor jasa.

Berikut ini grafik tingkat pengangguran di Indonesia pada tahun $1986-2016$ 
Gambar IV-1

Grafik Tingkat Pengangguran Indonesia Tahun 1986- 2016

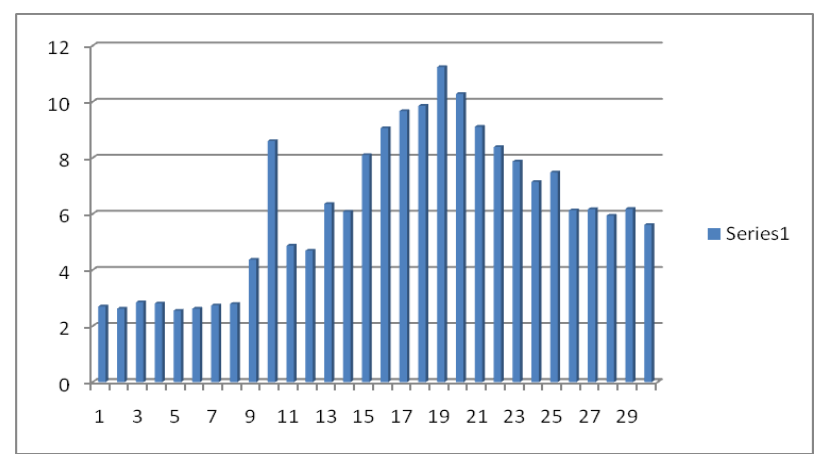

Tabel IV-2. Jumlah Angkatan Kerja, Pengangguran Terbuka dan Tingkat Pengangguran Terbuka di Indonesia Tahun 1986- 2016

\begin{tabular}{|c|c|c|c|}
\hline Tahun & Angkatan Kerja & $\begin{array}{c}\text { Pengangguran } \\
\text { Terbuka }\end{array}$ & $\begin{array}{c}\text { Tingkat Pengangguran } \\
\text { Terbuka }\end{array}$ \\
\hline 1986 & 67.202 .063 & 1.817 .672 & 2.70 \\
\hline 1987 & 69.398 .467 & 1.819 .507 & 2.62 \\
\hline 1988 & 71.559 .336 & 2.040 .718 & 2.85 \\
\hline 1989 & 74.464 .882 & 2.038 .158 & 2.81 \\
\hline 1990 & 75.016 .338 & 1.911 .800 & 2.55 \\
\hline 1991 & 75.903 .739 & 1.992 .115 & 2.62 \\
\hline 1992 & 78.027 .582 & 2.136 .021 & 2.74 \\
\hline 1993 & 78.917 .475 & 2.199 .210 & 2.79 \\
\hline 1994 & 83.324 .162 & 3.636 .932 & 4.36 \\
\hline 1995 & 84.230 .000 & 3.571 .352 & 4.24 \\
\hline 1996 & 87.827 .775 & 4.275 .414 & 4.87 \\
\hline 1997 & 89.230 .978 & 4.183 .971 & 4.69 \\
\hline 1998 & 92.337 .801 & 5.045 .260 & 5.46 \\
\hline 1999 & 94.847 .178 & 6.030 .319 & 6.36 \\
\hline 2000 & 95.650 .961 & 5.813 .231 & 6.08 \\
\hline 2001 & 98.812 .448 & 8.005 .031 & 8.10 \\
\hline 2002 & 100.779 .270 & 9.132 .104 & 9.06 \\
\hline 2003 & 102.750 .092 & 9.939 .301 & 9.67 \\
\hline 2004 & 103.973 .387 & 10.251 .351 & 9.86 \\
\hline 2005 & 105.857 .653 & 11.899 .266 & 11.24 \\
\hline 2006 & 106.380 .935 & 10.932 .000 & 10.28 \\
\hline 2007 & 109.941 .359 & 10.011 .142 & 9.11 \\
\hline 2008 & 111.947 .265 & 9.394 .515 & 8.39 \\
\hline 2009 & 113.833 .280 & 8.962 .617 & 7.87 \\
\hline 2010 & 116.527 .546 & 8.319 .779 & 7.14 \\
\hline 2011 & 116.097 .701 & 8.681 .392 & 7.48 \\
\hline 2012 & 119.849 .734 & 7.344 .866 & 6.13 \\
\hline 2013 & 120.172 .003 & 7.410 .931 & 6.17 \\
\hline 2014 & 121.872 .931 & 7.244 .905 & 5.94 \\
\hline 2015 & 122.380 .021 & 7.560 .822 & 6.18 \\
\hline 2016 & 125.443 .748 & 7.031 .775 & 5.61 \\
\hline
\end{tabular}

\section{Tingkat Inflasi}

Fakta bahwa inflasi pada dasawarsa 1960-an pernah mencapai lebih dari 635\% merupakan pengalaman pahit bagi pemerintah maupun seluruh 
masyarakat Indonesia. Sejak saat itu, pemerintah berusaha untuk mengendalikan laju inflasi dan variabel-variabel ekonomi makro lainnya melalui strategi pembangunan jangka panjang terarah dan terencana yang dimulai pada tahun 1969. Hasilnya, pada tahun 1969-1971 inflasi berada pada level dibawah $10 \%$, tahun 1972 sampai dengan tahun 1980an laju inflasi rata-rata berada pada level dua digit, dan pada tahun 1984 sampai tahun 1996 laju inflasi dapat dikendalikan pada level satu digit. Sayangnya, krisis moneter pada tahun 1997 membuat laju inflasi kembali naik menjadi 77,63\% pada tahun 1998 .

Pasca krisis moneter, perekonomian Indonesia mulai mengalami perbaikan, sehingga antara tahun 1998 dan 2009 laju inflasi kembali dapat dapat dikendalikan oleh pemerintah melalui berbagai instrumen kebijakan. Pentingnya pengendalian inflasi didasarkan pertimbangan bahwa inflasi tinggi dan tidak stabil akan memberikan dampak negatif kepada kondisi sosial ekonomi masyarakat. Pertama, inflasi yang tinggi akan menyebabkan pendapatan riil masyarakat akan terus turun sehingga standar hidup masyarakat juga akan turun. Kedua, inflasi yang tidak stabil akan menciptakan ketidakpastian bagi masyarakat dalam mengambil keputusan konsumsi, investasi dan produksi, yang pada akhirnya akan menurunkan pertumbuhan ekonomi. Ketiga, inflasi domestik yang lebih tinggi dibandingkan tingkat inflasi di negara tetangga menjadikan tingkat bunga domestik riil menjadi tidak kompetitif sehingga dapat memberikan tekanan pada nilai rupiah.

Tabel IV-3. Tingkat Inflasi Berdasarkan IHK Tahun 1969 - 2016

\begin{tabular}{|c|c|c|c|c|c|c|c|c|c|}
\hline Tahun & Inflasi & Tahun & Inflasi & Tahun & Inflasi & Tahun & Inflasi & Tahun & Inflasi \\
\hline 1969 & 9,89 & 1979 & 21,77 & 1989 & 5,97 & 1999 & 2,00 & 2009 & 2,78 \\
\hline 1970 & 8.88 & 1980 & 15,97 & 1990 & 9,53 & 2000 & 9,40 & 2010 & 6,96 \\
\hline 1971 & 2.47 & 1981 & 7,09 & 1991 & 9,52 & 2001 & 12,55 & 2011 & 3,79 \\
\hline 1972 & 25,84 & 1982 & 9,69 & 1992 & 4,94 & 2002 & 10,03 & 2012 & 4,30 \\
\hline 1973 & 23,30 & 1983 & 11,46 & 1993 & 9,77 & 2003 & 5,16 & 2013 & 8,38 \\
\hline 1974 & 33,32 & 1984 & 8,76 & 1994 & 9.24 & 2004 & 6,40 & 2014 & 8,36 \\
\hline 1975 & 19,69 & 1985 & 4,31 & 1995 & 8,60 & 2005 & 17,11 & 2015 & 3,35 \\
\hline 1976 & 14,20 & 1986 & 8,83 & 1996 & 6,50 & 2006 & 6,60 & 2016 & 3,02 \\
\hline 1977 & 11,82 & 1987 & 8,90 & 1997 & 11,10 & 2007 & 6,59 & - & - \\
\hline 1978 & 6,69 & 1988 & 5,87 & 1998 & 77,60 & 2008 & 11,06 & - & - \\
\hline
\end{tabular}

Sumber : BPS dan BI, diolah

Secara historis, tingkat dan volatilitas inflasi Indonesia lebih tinggi dibanding negara-negara berkembang lainnya. Ketika negara-negara berkembang lain memiliki rata-rata tingkat inflasi tahunan antara $3 \%$ sampai $5 \%$ pada periode 2005-2014, Indonesia memiliki rata-rata tingkat inflasi tahunan sekitar $8,5 \%$ dalam periode yang sama. 
Gambar IV-2. Tingkat Inflasi di Indonesia Tahun 1986-2016

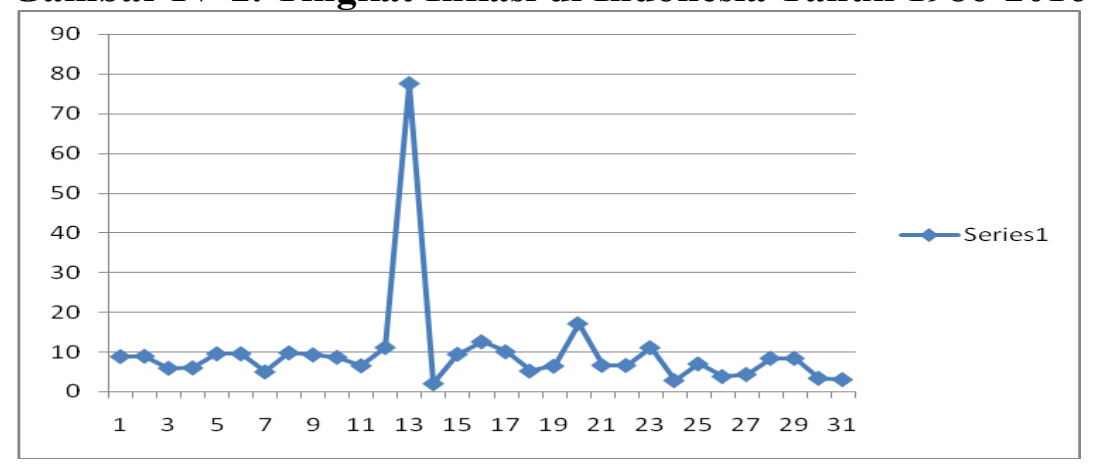

Karakteristik inflasi yang tidak stabil di Indonesia menyebabkan deviasi yang lebih besar dibandingkan dari proyeksi inflasi tahunan oleh Bank Indonesia. Akibat dari ketidakjelasan inflasi semacam ini adalah terciptanya biaya-biaya ekonomi, seperi biaya pinjaman yang lebih tinggi dibandingkan dengan negara-negara berkembang lainnya.

Kurangnya kuantitas dan kualitas infrastruktur di Indonesia juga mengakibatkan biaya ekonomi yang tinggi. Hal ini menghambat konektivitas antar daerah/pulau dan karenanya meningkatkan biaya trasnportasi untuk jasa dan produk. Hal ini membuat biaya logistik tinggi dan iklim investasi negara ini menjadi kurang menarik.

Harga-harga bahan pangan yang tidak stabil di Indonesia karena rentan terhadap kondisi cuaca juga menyebabkan tekanan inflasi. Harga-harga makanan yang tinggi menyebabkan kemiskinan yang serius. Panen yang gagal dikombinasikan dengan reaksi pemerintah yang lambat untuk mengganti produk lokal dengan produk impor turut menambah tekanan inflasi.

Ke depan, koordinasi Bank Indonesia dan pemerintah melalui Tim Pemantauan dan Pengendalian Inflasi melalui TPI dan TPID akan terus diperkokoh agar sasaran inflasi dapat dicapai secara konsisten pada periode mendatang.

\section{Analisis Kuantitatif}

\section{Analisis Korelasi}

Analisis korelasi dilakukan untuk menjawab pertanyaan penelitian yaitu bagaimana kesesuaian antara teori Kurva Phillips dan hukum Okun dengan kondisi perekonomian Indonesia pada tahun 1986 - 2016.

\section{a. Kurva Phillips}

Pada tahun 1958, ekonom yang bernama A.W. Phillips menerbitkan sebuah artikel pada jurnal Inggris "Economica". Artikel tersebut berjudul "The Relationship between Unemployment and the Rate of Change of Money Wages in the United Kingdom 1861-1957”. Dalam artikel tersebut, Phillips menunjukkan korelasi negatif antara tingkat pengangguran dan tingkat inflasi. Dengan kata lain, Phillips menunjukkan bahwa 


$\begin{array}{lrr}\text { tahun-tahun } & \text { dengan } & \text { tingkat } \\ \text { pengangguran yang } & \text { rendah } \\ \text { cenderung memiliki } & \text { tingkat } \\ \text { inflasi yang } & \text { tinggi, sedangkan } \\ \text { tahun-tahun } & & \text { dengan } \\ \text { pengangguran yang } & \text { tinggi } \\ \text { cenderung memiliki } & \text { inflasi } \\ \text { rendah. }\end{array}$

Gambar IV-3

Hubungan Antara Tingkat Pengangguran dan Tingkat Inflasi Tahun 1986-2016

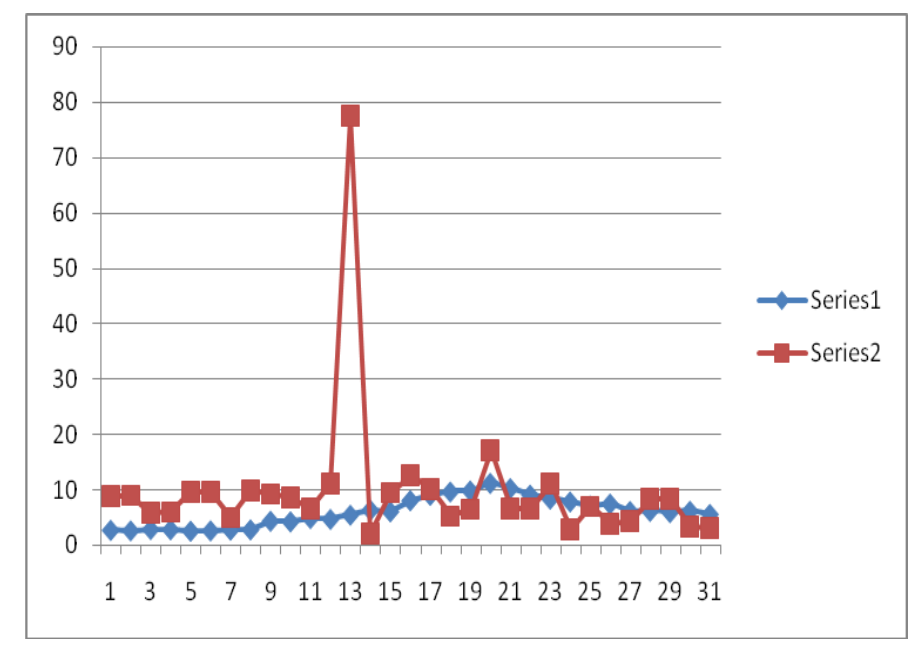

Pengolahan data dengan menggunakan analisis korelasi Pearson, diperoleh hasil sebagai berikut:

Tabel IV.4

Hasil Analisis Korelasi Pearson (Kurva Phillips)

Correlations

\begin{tabular}{|ll|r|r|}
\hline & & Pengangguran & \multicolumn{1}{|c|}{ Inflasi } \\
\hline Pengangguran & Pearson Correlation & 1 &,- 016 \\
& Sig. (2-tailed) & &, 931 \\
& $\mathrm{~N}$ & 31 & 31 \\
\hline Inflasi & Pearson Correlation &,- 016 & 1 \\
& Sig. (2-tailed) &, 931 & \\
& $\mathrm{~N}$ & 31 & 31 \\
\hline
\end{tabular}

Koefisien korelasi adalah Untuk bentuk/arah hubungan, nilai indeks atau bilangan yang digunakan koefisien korelasi dinyatakan dalam untuk mengukur derajat hubungan, positif $(+)$ dan negatif $(-)$, atau $(-1$ meliputi kekuatan hubungan dan $<\mathrm{KK}<+1)$.

bentuk/arah hubungan. Untuk kekuatan hubungan, nilai koefisien korelasi berada di antara -1 dan +1 .
1. Jika koefisien korelasi bernilai positif maka variabel-variabel berkorelasi positif. Artinya jika 
variabel yang satu naik maka variabel yang lainnya juga naik. Jika variabel yang satu turun maka yang lain juga turun. Semakin dekat nilai koefisien korelasi ke +1 , semakin kuat korelasi positifnya.

2. Jika koefisien korelasi bernilai negatif maka variabel-variabel berkorelasi negatif, artinya jika variabel yang satu naik maka variabel yang lainnya akan turun. Semakin dekat nilai koefisien korelasi ke -1 . semakin kuat korelasi negatifnya.

3. Jika koefisien korelasi bemilai 0 (nol) maka variabel tidak menunjukkan korelasi. Jika koefisien korelasi bernilai +1 atau -1 maka variabel-variabel menunjukkan korelasi positif atau negatif sempurna.

Dari tabel 4.5. diatas, dapat dilihat bahwa nilai koefisien korelasinya sebesar $-0,16$ dengan nilai signifikansi 0,931. Dari angka tersebut, dapat disimpulkan bahwa terdapat hubungan yang negatif tetapi tidak signifikan antara inflasi dan pengangguran di Indonesia pada tahun 1986 - 2016. Hal ini terjadi karena inflasi yang terjadi di Indonesia bukan disebabkan karena naiknya jumlah permintaan agregat (demand-pull inflation) yang pada akhirnya akan menurunkan tingkat pengangguran, tetapi kenaikan inflasi di Indonesia pada umumnya disebabkan karena naiknya biaya produksi seperti harga BBM, tarif listrik ataupun biaya produksi lainnya (cost-push inflation). Selain masalah harga BBM dan tarif listrik, kurangnya kuantitas dan kualitas infrastruktur di Indonesia juga menyebabkan ekonomi biaya tinggi, yang pada akhirnya dibebankan pada harga jual produksi, dan akan menyebabkan terjadinya inflasi.

\section{b. Hukum Okun}

Hukum Okun menyatakan bahwa untuk setiap penurunan 2 persen GDP yang berhubungan dengan GDP potensial, angka pengangguran meningkat sekitar 1 persen, demikian sebaliknya. Hukum Okun menyediakan hubungan yang sangat penting antara pasar output dan pasar tenaga kerja, yang menggambarkan asosiasi antara pergerakan jangka pendek pada GDP riil dan perubahan angka pengangguran.

Jika digambarkan dalam sebuah chart, maka hubungan antara pertumbuhan ekonomi dan pengangguran di Indonesia pada tahun 1986-2016 dapat dilihat pada gambar dibawah ini:

Gambar 4.6.

Hubungan Antara Tingkat Pengangguran dan Tingkat Pertumbuhan Ekonomi Tahun 1986-2016

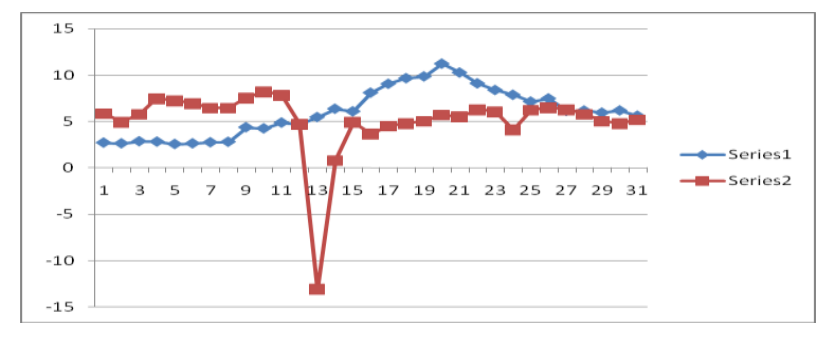


Pengolahan data dengan menggunakan analisis korelasi Pearson, diperoleh hasil sebagai berikut:

\section{Tabel IV.5}

Hasil Analisis Korelasi Pearson (Hukum Okun)

\begin{tabular}{|ll|r|r|}
\hline \multicolumn{2}{c|}{ Correlations } \\
\hline Pengangguran & Pengangguran & Pertumbuhan \\
& Pearson Correlation & 1 &,- 110 \\
& Sig. (2-tailed) & &, 556 \\
& $\mathrm{~N}$ & 31 & 31 \\
\hline Pertumbuhan & Pearson Correlation &,- 110 & 1 \\
& Sig. (2-tailed) &, 556 & \\
& $\mathrm{~N}$ & 31 & 31 \\
\hline
\end{tabular}

Dari tabel 4.7. diatas, dapat dilihat bahwa nilai koefisien korelasinya sebesar $-0,110$ dengan nilai signifikansi 0,556. Dari angka tersebut, dapat disimpulkan bahwa terdapat hubungan yang negatif tetapi tidak signifikan antara pertumbuhan ekonomi dan pengangguran di Indonesia pada tahun 1986-2016.

Hasil analisis tersebut mengindikasikan bahwa pertumbuhan ekonomi yang ada di Indonesia bukan merupakan pertumbuhan ekonomi yang berkualitas. Pertumbuhan ekonomi yang berkualitas adalah pertumbuhan ekonomi yang mampu meningkatkan kesejahteraan rakyat dan menyerap angkatan kerja. Selama dua tahun terakhir ini, tiga sektor yang mencatat pertumbuhan tertinggi dan mendorong pertumbuhan ekonomi bukanlah sektor yang padat karya, yaitu sektor pengangkutan dan komunikasi, jasa keuangan dan asuransi dan serta sektor perdagangan, hotel dan restoran.

Dengan tingkat pertumbuhan ekonomi tahun 2016 sebesar 5,02\%, terjadi penurunan terbuka dari 7,56 juta orang menjadi 7,02 juta orang, elastisitas pertumbuhan ekonomi terhadap penciptaan lapangan kerja adalah $1 \%$ pertumbuhan ekonomi menyerap 107.206 tenaga kerja.
Elastisitas tersebut menurun bila dibandingkan dengan elastisitas tahuntahun sebelumnya. Pada tahun 2014, elastisitas pertumbuhan ekonomi terhadap penciptaaan lapangan kerja adalah $1 \%$ dapat menyerap 260.000 tenaga kerja, bahkan pada tahun 2004 setiap 1\% pertumbuhan ekonomi dapat menerap 400.000 tenaga kerja.

\section{KESIMPULAN}

Berdasarkan hasil analisis deskriptif dan analisis korelasi yang telah dilakukan, dapat diambil kesimpulan sebagai berikut:

1. Untuk kesesuaian kurva Phillip dengan kondisi perekonomian Indonesia pada tahun 1986-2016, dari hasil analisis data diperoleh nilai koefisien korelasi sebesar 0,16 dengan nilai signifikansi 0,931. Dari angka tersebut, dapat disimpulkan bahwa terdapat hubungan yang negatif tetapi tidak signifikan antara inflasi dan pengangguran di Indonesia pada tahun 1986 - 2016. Hal ini terjadi karena inflasi yang terjadi di Indonesia bukan disebabkan karena naiknya jumlah permintaan agregat (demand-pull inflation) yang pada akhirnya akan menurunkan tingkat 
pengangguran, tetapi kenaikan inflasi di Indonesia pada umumnya disebabkan karena naiknya biaya produksi seperti harga BBM, tarif listrik ataupun biaya produksi lainnya (cost-push inflation).

2. Untuk kesesuaian hukum Okun dengan kondisi perekonomian Indonesia pada tahun 1986-2016, dari hasil analisis data diperoleh nilai koefisien korelasi sebesar 0,110 dengan nilai signifikansi 0,556. Dari angka tersebut, dapat disimpulkan bahwa terdapat hubungan yang negatif tetapi tidak signifikan antara pertumbuhan ekonomi dan pengangguran di Indonesia pada tahun 1986-2016. Hasil analisis tersebut mengindikasikan bahwa pertumbuhan ekonomi yang ada di Indonesia bukan merupakan pertumbuhan ekonomi yang berkualitas. Pertumbuhan ekonomi yang berkualitas adalah pertumbuhan ekonomi yang mampu meningkatkan kesejahteraan rakyat dan menyerap angkatan kerja.

\section{DAFTAR PUSTAKA}

Badan Pusat Statistik. Indikator Ekonomi. Jakarta

Boediono. 1992. Teori Pertumbuhan Ekonomi : Seri Sinopsis Pengantar Ilmu Ekonomi No.4. Yogyakarta : BPFE

Boediono. 1985. Ekonomi Makro : Seri Sinopsis Pengantar Ilmu Ekonomi No. 2. Cetakan Keempat. Yogyakarta : BPFE

Case, Karl. E , Ray C. Fair. 2004. Principles of Macroeconomics. $7^{\text {th }}$ Edition. Prentice Hall Business Publishing

Gujarati, Damodar. 1995. Ekonometrika Dasar. Jakarta : Erlangga

Ghozali, Imam. 2005. Aplikasi Analisis Multivariate Dengan Program SPSS. Edisi 3. Semarang : UNDIP

Insukindro. 2003. Model Pelatihan Ekonometrika. Yogyakarta : UGM

Jhingan,M.L. 2004. Ekonomi Pembangunan dan Perencanaan. Cetakan Kesepuluh. Jakarta : Raja Grafindo Persada

Mankiw, Gregory N. 2006. Pengantar Ekonomi Makro. Jakarta : Salemba Empat

Murni, Asfia. 2006. Ekonomi Makro. Bandung : PT. Refika Aditama

Nanga, Muana. 2001. Makroekonomi : Teori, Masalah dan Kebijakan. Edisi Perdana. Jakarta : Raja Grafindo Persada

Raharja, Pratama. 2008. Pengantar Ilmu Ekonomi (Mikroekonomi dan Makroekonomi). Jakarta : Lembaga Penerbit FEUI

Sukirno, Sadono. 1994. Pengantar Teori Makroekonomi. Cetakan Kedua. Jakarta: Raja Grafindo Persada

Sukirno, Sadono. 2000. Makroekonomi Modern. Jakarta : Raja Grafindo Persada

Sukirno, Sadono. 2006. Ekonomi Pembangunan : Proses, Masalah dan dasar Kebijakan. Cetakan Kedua. Jakarta : Kencana Prenada Media.

Suryana. 2000. Ekonomi Pembangunan : Problematika dan Pendekatan. Jakarta: Salemba Empat 